\title{
Corticotrophin Therapy in Juvenile Chronic Polyarthritis (Still's Disease) and Effect on Growth
}

\author{
DEREK W. ZUTSHI, MAX FRIEDMAN, and BARBARA M. ANSELL \\ From the Medical Research Council, Rheumatism Research Unit, Canadian Red Cross Memorial Hospital, Taplow, \\ and University College Hospital and the Whittington Hospital, London
}

Zutshi, D. W., Friedman, M., and Ansell, B. M. (1971). Archives of Disease in Childhood, 46, 584. Corticotrophin therapy in juvenile chronic polyarthritis (Still's disease) and effect on growth. ACTH therapy will satisfactorily control acute systemic manifestations in Still's disease. In this particular type of patient, ACTH treatment is preferable to oral corticosteroids, because (a) growth can be maintained, and (b) once the acute symptoms are brought under control, ACTH can be withdrawn without difficulty. On the other hand, with ACTH the arthritis is more difficult to control, and here its role may well be as a temporary measure while other drugs, such as gold, can take effect.

If corticosteroid therapy cannot be withdrawn well before puberty, then conversion to ACTH should be seriously considered, in order to gain the advantage of the pubertal growth spurt.

ACTH dosage should aim to allow endogenous ACTH production to occur. This can be gauged by measuring the 9 a.m. resting plasma cortisol levels 48 hours after ACTH administration. Concurrent use of ACTH and corticosteroids fails to maintain function of the hypothalamic pituitary adrenal axis.

In juvenile chronic polyarthritis (Still's disease), as in other chronic diseases of childhood, general retardation of growth may occur as a result of the disease itself, particularly when the inflammatory process remains active over a period of years (Ansell and Bywaters, 1956). The retardation of growth in height may be intensified by maintenance daily corticosteroid therapy (Bywaters, 1965; Louyot et al., 1965; Ward, Hartog, and Ansell, 1966) which may be necessary if there are serious systemic manifestations, iridocyclitis, or when other forms of therapy have not been effective (Ansell and Bywaters, 1968).

Attempts to overcome corticosteroid-induced dwarfism by anabolic steroids (Ansell, 1968) and human growth hormone (Kammerer and Stokes, 1962; Ward et al., 1966; Tanner and Whitehouse, 1967; Morris et al., 1968) have met with only limited success. In 1966, Friedman and Strang reported that 9 juvenile patients, suffering from either asthma or the nephrotic syndrome, had an increased rate of growth when their therapy was changed from oral corticosteroids to corticotrophin

Received 5 April 1971
(ACTH); further, a patient with juvenile rheumatoid arthritis, who had been treated with ACTH and prednisone simultaneously for over seven years, grew at a normal rate.

This paper reports three separate studies on ACTH therapy in a group of children with Still's disease.

\section{First Study: Effect on Growth of Changing from Corticosteroid to ACTH Therapy}

This set out to show whether it was possible to improve linear growth in severely stunted cases by changing their maintenance treatment from daily oral corticosteroid to ACTH therapy.

Patients (Table I). Five children were selected. The age of onset of Still's disease varied from 0.7 to 5.7 years, and the duration of the disease from 3.6 to 11.5 years, so that they were aged from 6 to 13 years at conversion. All had received continuous corticosteroid therapy for a prolonged period ranging from $3 \cdot 1$ to $10 \cdot 7$ years, the average daily dose being equivalent to 4-8 mg prednisone. One was at the 10th centile of height, while the other 4 were below the 3rd centile. Four had severe arthritis, and one bilateral chronic 
TABLE I

First Study: Status of Cases

\begin{tabular}{l|l|c|c|c|c}
\hline $\begin{array}{l}\text { Case } \\
\text { No. }\end{array}$ & Sex & $\begin{array}{c}\text { Age of } \\
\text { Onset of } \\
\text { Disease } \\
\text { (yr) }\end{array}$ & $\begin{array}{c}\text { Duration } \\
\text { of } \\
\text { Disease } \\
\text { (yr) }\end{array}$ & $\begin{array}{c}\text { Duration } \\
\text { of Corti- } \\
\text { costeroid } \\
\text { (yr) }\end{array}$ & $\begin{array}{c}\text { Height } \\
\text { Centile at } \\
\text { Start } \\
\text { of Study }\end{array}$ \\
\hline 1 & F & $\mathbf{0 . 7}$ & $5 \cdot 3$ & $3 \cdot 1$ & $<3$ \\
2 & M & $1 \cdot 5$ & $11 \cdot 3$ & $8 \cdot 5$ & $<3$ \\
3 & F & $1 \cdot 7$ & $11 \cdot 5$ & $10 \cdot 7$ & $<3$ \\
4 & F & $3 \cdot 7$ & $8 \cdot 3$ & $8 \cdot 3$ & $<3$ \\
5 & F & $5 \cdot 7$ & $3 \cdot 6$ & $3 \cdot 1$ & 10 \\
\hline
\end{tabular}

iridocyclitis and arthritis. At the time of conversion the current prednisone dose, which in each case was at the lowest level necessary to control the disease activity, varied between 1.5 and $6 \mathrm{mg}$ daily.

Method. The ACTH used in this study was Acthar Gel (Armour) batch No. LF 3002 which had a potency of 39 international units per $\mathrm{ml}$.

Conversion to ACTH was carried out in the following manner. A resting plasma cortisol level, determined by the method of Mattingly (1962), was obtained immediately before the ACTH injection at 9.00 a.m. 40 units ACTH was then given intramuscularly 6 days a week until the plasma cortisol level 5 hours after the ACTH injection exceeded $35 \mu \mathrm{g} /$ $100 \mathrm{ml}$. Prednisone was then stopped, or progressively reduced, while other drug therapy, e.g. salicylate, was continued.

Clinical assessment including a record of the number of active joints, ${ }^{\star}$ and previously practised function tests, such as grip strength (in $\mathrm{mmHg}$ ) and walking time, were observed at the same time each morning before change of therapy, during the changeover, and then twice weekly during that admission. The ESR, $\mathrm{Hb}$, and WBC were determined twice weekly for the first four weeks and then weekly. The serum electrolytes were determined, and the urine tested for protein and sugar, once weekly.

ACTH was continued at the same dosage until the active joint count and the ESR were below the preliminary recordings. The ACTH was then reduced to $20 \mathrm{U}$ daily 6 days a week. This was continued until the previously satisfactory clinical state was obtained and maintained for 2 weeks. The ACTH was then reduced to $20 \mathrm{U}$ on alternate days. If the disease was not satisfactorily controlled after 2 weeks the dose was increased to $40 \mathrm{U}$ but the alternate-day regimen maintained. Our aim was to maintain stimulation of the adrenal gland for between 12 and 15 hours and obtain a measured cortisol response of between 30 and $50 \mu \mathrm{g} /$ $100 \mathrm{ml}$ plasma 5 hours after ACTH. Plasma cortisol levels were estimated at rest at 9.00 a.m. and 5 hours after stimulation daily during the period of changeover, weekly while an inpatient, and approximately monthly after discharge on maintenance therapy.

*A joint was considered to be active when there was soft tissue swelling, with either pain and/or limitation of movement.
The weight and standing height according to the method of Tanner, Whitehouse, and Takaishi (1966) were recorded at a fixed time early in the morning weekly from the beginning of the study. A 24-hour hydroxyproline excretion was estimated approximately weekly, by Jasin et al.'s modification of Prockop and Udenfriend's method (1962); after discharge from the ward, clinical assessments were carried out monthly. Radiological examination of the spine was carried out at the start of therapy, and repeated at 12-monthly intervals. Vertebral bodies were measured at the anterior border and at the middle of the body on the lateral films of the thoracic and lumbar spine to assess the effect of change of treatment on bone structure. Sixmonthly $x$-rays of the hands were also taken. During the study the serum of the patients was tested for antibodies to porcine ACTH (Landon, Friedman, and Greenwood, 1967).

Results. The 5 patients improved clinically with the addition of ACTH to their regimen. However, the stopping of prednisone was associated with a temporary increase in the number of active joints and a rise in ESR, so that it was necessary to maintain a moderately high dosage of ACTH for varying periods of time from 2 weeks to 10 months. In the patient with iridocyclitis (Case 5), this was not satisfactorily controlled.

Two patients (Cases 2 and 3) (Fig. 1) showed an increase in growth rate during the first year of therapy, while a third (Case 4) showed a slightly improved growth rate. Two patients (Cases 1 and 5) continued to grow at the same rate but one of these (Case 5) was withdrawn after 10 months of ACTH therapy (Table II). During the second year, the increased rate of growth continued in Cases 2 and 4, but fell off in Case 3. In the third year an increase in growth rate occurred in Cases 1 and 4 (Fig. 2) and while it continued in Case 2, it further fell away in Case 3.

Cortisol levels. Before ACTH therapy the 9.00

TABLE II

First Study: Linear Growth While on

Corticosteroids in Year Preceding and Subsequently on ACTH Therapy

\begin{tabular}{|c|c|c|c|c|}
\hline $\begin{array}{r}\text { Case } \\
\text { No. }\end{array}$ & $\begin{array}{l}\text { Growth (cm) } \\
\text { in Preceding } \\
\text { Year on } \\
\text { Corticosteroid } \\
\text { Therapy (cm) }\end{array}$ & $\begin{array}{c}\text { Growth } \\
\text { 1st Year } \\
\text { ACTH } \\
(\mathrm{cm})\end{array}$ & $\begin{array}{c}\text { Growth } \\
\text { 2nd Year } \\
\text { ACTH } \\
(\mathrm{cm})\end{array}$ & $\begin{array}{c}\text { Growth } \\
\text { 3rd Year } \\
\text { ACTH } \\
\text { (cm) }\end{array}$ \\
\hline $\begin{array}{l}1 \\
2 \\
3 \\
4 \\
5 \star\end{array}$ & $\begin{array}{l}5 \cdot 1 \\
0 \cdot 0 \\
4 \cdot 3 \\
0 \cdot 3 \\
2 \cdot 2^{\star}\end{array}$ & $\begin{array}{l}5 \cdot 1 \\
3 \cdot 2 \\
8 \cdot 9 \\
1 \cdot 0 \\
2 \cdot 2 \star\end{array}$ & $\begin{array}{l}5 \cdot 1 \\
5 \cdot 7 \\
4 \cdot 8 \\
1 \cdot 9 \\
-\end{array}$ & $\begin{array}{l}6 \cdot 4 \\
5 \cdot 1 \\
2 \cdot 2 \\
3 \cdot 8 \\
-\end{array}$ \\
\hline
\end{tabular}

$\star 10$ months only. 


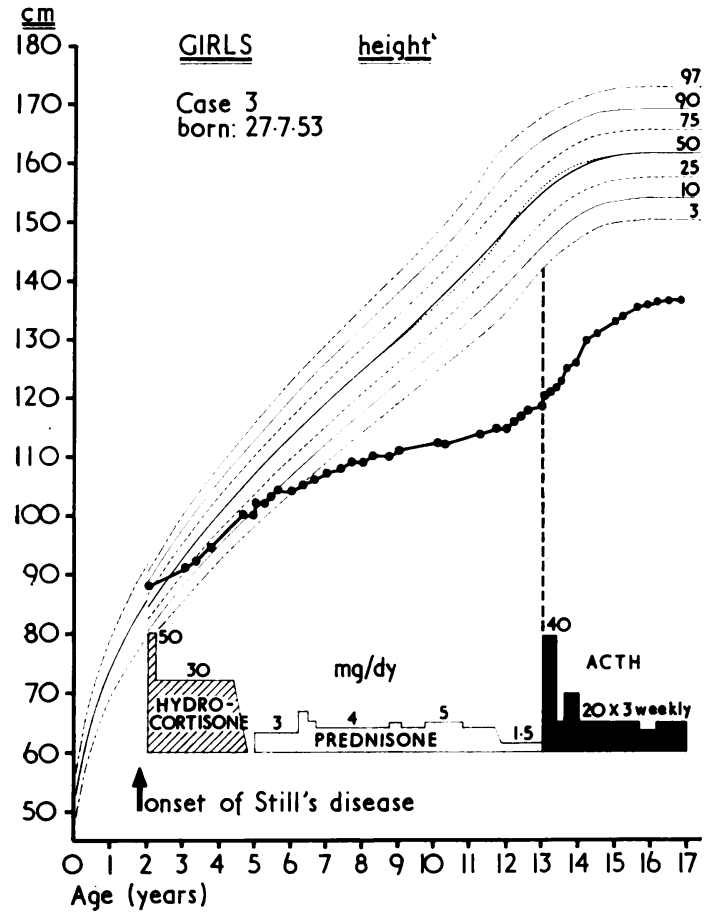

Fig. 1.-Case 3. Growth chart showing that during the period of corticosteroid therapy she fell from the 50th centile to well below the 3rd centile. After conversion to $A C T H$ her growth increased particularly in the first year.

a.m. ('resting') plasma cortisol levels were all below the lower limit of normal for this time of day $(6 \mu \mathrm{g} / 100 \mathrm{ml}$ ) except in one patient (Case 2) in whom it was $11 \mu \mathrm{g}$ (Table III). All these patients had a reduced adrenal response 5 hours after their first injection of ACTH. The post-injection plasma cortisol level ranged from $2 \cdot 2$ to $32 \cdot 4 \mu \mathrm{g} / 100 \mathrm{ml}$. The larger the current daily dose of prednisone the smaller the response was to ACTH; moreover, the

\section{TABLE III}

First Study: Adrenal Response at Start of ACTH Therapy

\begin{tabular}{|c|c|c|c|c|}
\hline \multirow{2}{*}{$\begin{array}{l}\text { Case } \\
\text { No. }\end{array}$} & \multirow{2}{*}{$\begin{array}{l}\text { Current } \\
\text { Dosage } \\
\text { Prednisone } \\
\text { (mg/day) }\end{array}$} & \multicolumn{2}{|c|}{$\begin{array}{l}\text { Initial Plasma Cortisol } \\
\qquad(\mu \mathrm{g} / 100 \mathrm{ml})\end{array}$} & \multirow{2}{*}{$\begin{array}{c}\text { Duration of } \\
\text { ACTH Therapy } \\
\text { Before Normal } \\
\text { Adrenal } \\
\text { Response (dy) }\end{array}$} \\
\hline & & 9.00 a.m. & $\begin{array}{c}5 \mathrm{hr} \text { after } \\
40 \mathrm{U} \mathrm{ACTH}\end{array}$ & \\
\hline $\begin{array}{l}1 \\
2 \\
3 \\
4 \\
5\end{array}$ & $\begin{array}{l}3 \\
3 \\
1 \cdot 5 \\
5 \\
6\end{array}$ & $\begin{array}{r}2 \cdot 0 \\
11 \cdot 0 \\
5 \cdot 4 \\
2 \cdot 2 \\
0 \cdot 8\end{array}$ & $\begin{array}{r}18 \cdot 0 \\
26 \cdot 6 \\
32 \cdot 4 \\
23 \cdot 2 \\
2 \cdot 2\end{array}$ & $\begin{array}{r}5 \\
4 \\
2 \\
4 \\
19\end{array}$ \\
\hline
\end{tabular}

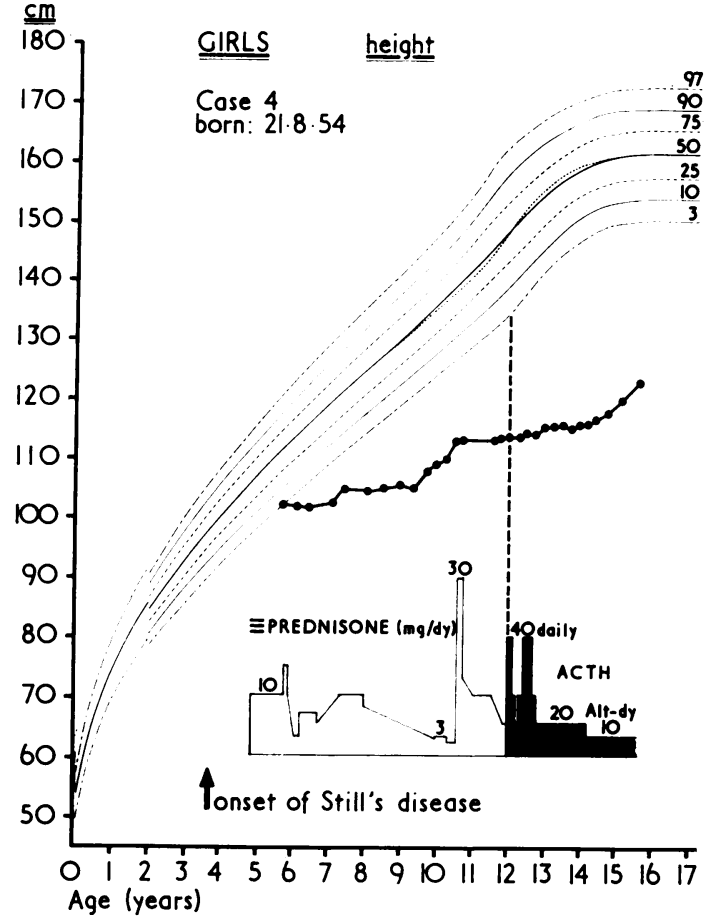

Fig. 2.-Case 4. Growth chart showing only minimal improvement in growth rate until the third year of ACTH therapy.

time for the normal adrenal response $(35 \mu \mathrm{g} / 100 \mathrm{ml})$ to be obtained varied directly with the size of the previous prednisone dose. Improvement in the growth rate did not occur until the patients had been established on an alternate-day regimen of ACTH and there was a rise in the 9.00 a.m. plasma cortisol to normal levels.

Hydroxyproline excretion. All 5 children were in a non-growing phase initially. In those children whose growth improved, a rise in excretion occurred concurrently with the increase in growth.

Antibodies to porcine ACTH. Antibodies were looked for in Case 5 at 10 months when the ACTH was stopped, and in Case 1 at the end of 1 year's treatment. Neither case had antibodies present; neither had shown an improved growth rate. Antibodies were present after two years of therapy in the remaining 3 cases, 2 of which had shown a marked improvement in growth rate and 1 a minimal improvement.

Spinal state. Cases 1 and 3 showed increase in height of all vertebrae at each appraisal throughout 
the three years of treatment. Case 2 showed some increase in height of two vertebrae at the end of the first year and at the second year increase in height of all vertebrae. At 1 year Case 4 showed a marked decrease in one vertebra due to collapse and at 2 years 6 vertebrae showed slight reduction in height; however, in the third year all vertebrae grew. During the 10 months of treatment of Case 5 there was no change in vertebral size.

Bone age from hand $\mathrm{x}$-rays. All the children except Case 5 had severe erosive arthritis affecting the carpus and hand so that accurate assessment of bone age and the effect of therapy on it was not possible. In Case 5 the bone age was more than one year behind the chronological age and during the next year advanced less than one year.

Complications. Most of the children developed more marked cushingoid facies and gained weight; two developed hypokalaemia which was easily corrected with potassium supplements. Transient hypertension developed in two patients. One had previously had a nephrectomy; she was withdrawn from the study after 10 months because of the hypertension and because of her chronic iridocyclitis which had proved difficult to control. There was no evidence of amyloidosis in this or any of the other patients. The other child whose blood pressure tended to rise had progressive weight gain; the obesity was difficult to correct by diet and in addition mild hypokalaemia occurred.

\section{Second Study: ACTH as Initial Therapy}

In view of the results of the first study it was decided to use ACTH instead of oral corticosteroid as the initial treatment in patients in whom steroid therapy was indicated on clinical grounds. The aim was to ascertain how easily the disease could be controlled and whether in children who had not received previous oral corticosteroid therapy, growth could be maintained.

Patients. Seven children who were not responding to a full conservative regimen not including steroids were started on ACTH (Table IV). There were 6 girls and 1 boy aged from 2.5 to 11.5 years; the duration of the disease varied from 0.2 to 5.5 years. Only one patient was at the third centile in height. Cases 6 and 8 had severe pericarditis with pyrexia, Cases 10 and 12 had persistent pyrexia and anaemia as well as severe arthritis, while the remaining 3 children had uncontrolled arthritis.

Method. ACTH gel from the same batch (LF 3002) was used.
TABLE IV

Second Study: Status of Cases

\begin{tabular}{c|c|c|c|c}
\hline $\begin{array}{c}\text { Case } \\
\text { No. }\end{array}$ & Sex & $\begin{array}{c}\text { Age at Onset } \\
\text { of Disease } \\
\text { (yr) }\end{array}$ & $\begin{array}{c}\text { Duration } \\
\text { of Disease } \\
\text { (yr) }\end{array}$ & $\begin{array}{c}\text { Height Centile } \\
\text { at Start } \\
\text { of Study }\end{array}$ \\
\hline 6 & F & $2 \cdot 5$ & $0 \cdot 5$ & 75 \\
7 & F & $2 \cdot 8$ & $0 \cdot 2$ & $<50$ \\
8 & F & $3 \cdot 0$ & $4 \cdot 2$ & $10-25$ \\
9 & F & $3 \cdot 9$ & $2 \cdot 7$ & 3 \\
10 & F & $4 \cdot 3$ & 1.9 & 75 \\
11 & F & $5 \cdot 5$ & $5 \cdot 5$ & $<25$ \\
12 & M & $11 \cdot 5$ & 0.2 & $>75$ \\
\hline
\end{tabular}

The ACTH therapy was added to the therapeutic regimen as a single morning intramuscular dose of 20 to 80 units daily according to the severity of the systemic or arthritic manifestations; it was continued at this level until the acute manifestations were controlled, and then rapidly reduced to 40 and then 20 units on alternate days. Clinical management and assessment, and haematological, biochemical, and radiological investigations were carried out as in the first study; but hydroxyproline estimations and antibodies to ACTH were only checked in 2 cases.

Results. Rapid and satisfactory control of the systemic manifestations was obtained in all cases. Similarly, while the more severe arthritic manifestations improved with reduction of the ACTH to maintenance levels of 20 and $40 \mathrm{U}$ on alternate days, this improved joint state was not always maintained. Myocrisin was added to the regimen in Cases 6 and 10 and continued in Cases 8 and 9 . Because of the joint deterioration in Case 6 , increases in dose and return to daily regimen for a period were necessary. Growth in height was maintained without interruption in 6 of the 7 children (Table V), the values for the expected 50th centile growth were taken from the whole year height velocity standards laid down by Tanner et al. (1966). Though every effort was made to reduce and stop the ACTH therapy, this was not always possible, and indeed in one patient (Case 10) it has been necessary to continue this regimen for 4 years; during this period growth has been maintained (Fig. 3).

Cortisol levels. Cases 7, 9, 10, and 11 had resting plasma cortisol levels within the normal range. The levels 5 hours after ACTH were within the range of $35-50 \mu \mathrm{g} / 100 \mathrm{ml}$. In Case 6 where ACTH had to be increased and at times given daily in an attempt to control joint symptoms, gross hyperstimulation occurred so that the resting level was abnormally high and the 5-hour 
TABLE V

Second Study: Growth Rate over 2 Years in Cases Treated with ACTH Alone for Varying Periods

\begin{tabular}{|c|c|c|c|c|c|c|}
\hline \multirow[b]{2}{*}{ Case No. } & \multirow{2}{*}{$\begin{array}{c}\text { Height } \\
\text { Centile } \\
\text { at } \\
\text { Onset }\end{array}$} & \multirow{2}{*}{$\begin{array}{c}\text { Duration } \\
\text { of } \\
\text { ACTH } \\
\text { (months) }\end{array}$} & \multicolumn{2}{|c|}{ Growth During 1st Year (cm) } & \multicolumn{2}{|c|}{ Growth During 2nd Year (cm) } \\
\hline & & & Actual & $\begin{array}{c}\text { Expected } \\
\text { (50th Centile) }\end{array}$ & Actual & $\begin{array}{c}\text { Expected } \\
\text { (50th Centile) }\end{array}$ \\
\hline $\begin{array}{r}6 \\
7 \\
8 \\
9 \\
10 \\
11 \\
12\end{array}$ & $\begin{array}{r}75 \\
50 \\
>10 \\
3 \\
50-75 \\
25 \\
>75\end{array}$ & $\begin{array}{c}24 \\
21 \\
8 \\
24 \\
24 \\
6 \\
8 \cdot 5\end{array}$ & $\begin{array}{l}1 \cdot 7 \\
9 \cdot 8 \\
7 \cdot 2^{\star} \\
3 \cdot 1 \\
9 \cdot 5 \\
8 \cdot 7^{\star} \\
5 \cdot 6^{\star}\end{array}$ & $\begin{array}{l}7 \cdot 9 \\
7 \cdot 9 \\
5 \cdot 7 \\
5 \cdot 9 \\
6 \cdot 0 \\
6 \cdot 1 \\
4 \cdot 9\end{array}$ & $\begin{array}{l}1 \cdot 9 \\
5 \cdot 7 \star \\
7 \cdot 0 \dagger \\
5 \cdot 0 \\
6 \cdot 8 \\
5 \cdot 0 \dagger \\
5 \cdot 8 t\end{array}$ & $\begin{array}{l}7 \cdot 0 \\
7 \cdot 0 \\
5 \cdot 5 \\
5 \cdot 6 \\
6 \cdot 3 \\
6 \cdot 4 \\
5 \cdot 5\end{array}$ \\
\hline
\end{tabular}

*ACTH given during only first part of year.

tACTH not given.

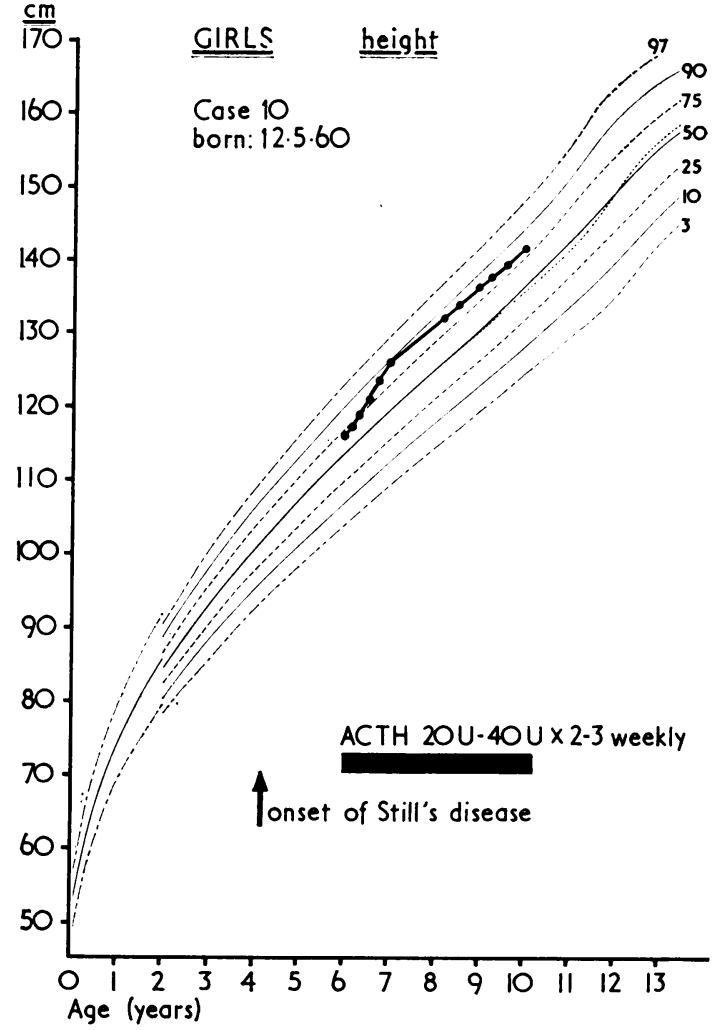

FIG. 3.-Case 10. Maintenance of satisfactory growth rate during 4 years of continuous $A C T H$ therapy.

level varied from 120 to $150 \mu \mathrm{g} / 100 \mathrm{ml}$ within 6 months of treatment. Over the next 12 months, as the dose was maintained in the region of $\mathbf{4 0}$ units on alternate days, the resting levels had not returned to normal 48 hours after stimulation. It was not until the dose was reduced and maintained at 20 o: 30 units on alternate days that the resting cortisol returned to normal and the 5-hour level fell within our defined desirable range. Plasma cortisol levels were not determined in Cases 8 and 12.

Antibodies to porcine ACTH. Cases 9 and 10, both of whom were growing, had no antibodies to porcine ACTH present in their serum.

Spinal state. At the start of therapy only Case 9 had evidence of vertebral collapse; in each of the ensuing 3 years there was an increase in vertebral size. Case 6 showed a loss of height in 2 vertebrae with conspicuous collapse in one at the end of the first year of therapy, and a further vertebra collapsed during the second year of therapy. In the third year the previously collapsed vertebrae had grown, another vertebra had lost $0.4 \mathrm{~cm}$ in height, but all the other vertebrae showed some increase in growth. In the remaining 5 cases all vertebrae had increased in size during the first and second year.

Bone age from hand $\mathrm{x}$-rays. In the one patient (Case 12) in whom there was only minor wrist involvement, the bone age on the hand $x$-ray was the same as the chronological age before and 1 year after the start of therapy.

In 2 patients (Cases 6 and 8) there was rapidly progressive carpal involvement, making assessment of the effect of therapy on bone age impossible, while in a further two (Cases 9 and 11) the initial $x$-rays made accurate assessment of bone age impossible. In Case 10 the involved left carpus was 6 months in advance of the right; both carpi grew satisfactorily during the years of ACTH therapy.

Complications. Apart from mild obesity, and 
minimal mooning in 2 (Cases 3 and 10), Case 6 was the only patient to show complications; she became grossly cushingoid with collapse of vertebrae.

\section{Illustrative case histories}

Case 6. A girl aged $2 \frac{1}{2}$ had an acute onset with fever, rash, and pericarditis, and these were initially controlled with ACTH, but when this was reduced to $40 \mathrm{U}$ on alternate days the arthritis worsened. To control this the dosage of ACTH was increased to 60 and then $80 \mathrm{U}$, and at times was given daily, causing her to become cushingoid, with gross biochemical evidence of hyperstimulation of the adrenals. In the first year of therapy she grew $1 \cdot 7$ $\mathrm{cm}$ and vertebrae collapsed. Similarly, in the second year she grew only $1.9 \mathrm{~cm}$ and further vertebrae collapsed. Towards the end of the second year of therapy and after the introduction of gold therapy it was possible to reduce her ACTH to 30 and later $20 \mathrm{U}$ on alternate days with subsequent improvement in her cushingoid state. The growth rate is improving in the third year.

Case 9. A girl aged $6 \frac{1}{2}$ years on admission who had had Still's disease for over $2 \frac{1}{2}$ years. During the previous 9 months rapid deterioration of her joints had occurred; she became unable to walk and while in bed developed multiple collapsed vertebrae. Despite a full conservative regimen over a 3 -month period, which included gold therapy, she remained unable to walk because of active arthritis with flexion contractures. $\mathrm{Hb}$ was $58 \%$ and ESR $111 \mathrm{~mm} / \mathrm{hr}$. ACTH was introduced at $20 \mathrm{U}$ on alternate days. Over the next 6 weeks correction of the contracture deformities of knees and feet was obtained, so that remobilization was possible. During the first 6 months of ACTH therapy no growth occurred but no further vertebrae collapsed, and then during the second 6 months she grew $3 \cdot 1 \mathrm{~cm}$. She grew $5 \mathrm{~cm}$ in the second year of therapy despite her disease process remaining active, and there was improvement in the state of her vertebrae.

\section{Third Study: Effect of Adding ACTH to Corticosteroid Therapy}

This study was to assess the state of the hypothalamic pituitary adrenal axis when ACTH had been added to daily oral corticosteroids.

Patients. Three patients were studied (Table VI). In Case 13 , the Still's disease started at $7 \cdot 1$ years, and at the time of the investigation the duration was $3 \cdot 7$ years. She had received prednisone for more than two years at an average dose of $10 \mathrm{mg} /$ day and ACTH for the previous four months at an average dose of $20 \mathrm{U}$ on alternate days; she was below the 10th centile of height. In Case 14 the age of onset was 7.9 and the duration of the disease was $4 \cdot 8$ years. She had received prednisone at an average dose exceeding $10 \mathrm{mg} /$ day and ACTH at dosages varying from 20 to $80 \mathrm{U}$ twice to thrice weekly, throughout her illness, except for the first two months; she was below the 3rd centile in height.
Case 15 had an age of onset at $6 \cdot 3$ years and the duration of disease was $6 \cdot 2$ years. She had been on prednisone at an average dose of $10 \mathrm{mg} /$ day for 5 years, with ACTH added for the last year initially daily for 3 months and on alternate days for a further 9 months, either 20 or $40 \mathrm{U}$. She was below the 3 rd centile of height.

\section{TABLE VI}

Third Study: Status of Cases

\begin{tabular}{c|c|c|c|c|c|c}
\hline $\begin{array}{c}\text { Case } \\
\text { No. }\end{array}$ & Sex & $\begin{array}{c}\text { Age at } \\
\text { Onset of } \\
\text { Disease } \\
\text { (yr) }\end{array}$ & $\begin{array}{c}\text { Duration } \\
\text { of } \\
\text { Disease } \\
\text { (yr) }\end{array}$ & $\begin{array}{c}\text { Duration } \\
\text { of Pred- } \\
\text { nisone } \\
\text { (yr) }\end{array}$ & $\begin{array}{c}\text { Duration } \\
\text { of } \\
\text { ACTH } \\
\text { (yr) }\end{array}$ & $\begin{array}{c}\text { Height } \\
\text { Centile at } \\
\text { Start of } \\
\text { Study }\end{array}$ \\
\hline 13 & F & $7 \cdot 1$ & $3 \cdot 7$ & $2 \cdot 2$ & $0 \cdot 3$ & $<10$ \\
14 & F & $7 \cdot 9$ & $4 \cdot 8$ & $4 \cdot 5$ & $4 \cdot 5$ & $<3$ \\
15 & F & $6 \cdot 3$ & $6 \cdot 2$ & $5 \cdot 0$ & $1 \cdot 0$ & $<3$ \\
\hline
\end{tabular}

Method. Treatment was continued unchanged while the response to $40 \mathrm{U}$ of ACTH was measured. On days free of ACTH therapy an insulin tolerance test (Cases 13, 14, and 15) taking the precautions outlined by Stimmler and Brown (1967), and a lysine8-vasopressin test (Cases 13 and 14) using 5 pressor units given by intramuscular injection were carried out. Other assessments and investigations were performed as outlined in the first study, after which Cases 13 and 14 were transferred to ACTH. In Case 15 the ACTH was stopped, gold therapy introduced, and the prednisone gradually withdrawn over one year.

Results. In all three patients the resting cortisol levels were depressed, but they showed a normal adrenal response to the standard test of $40 \mathrm{U}$ ACTH. However, the insulin tolerance and lysine-8-vasopressin tests failed to produce a normal increment in plasma cortisol levels. A satisfactory fall in blood sugar of more than $50 \%$ below the fasting level was achieved in the insulin tolerance test. This confirms that there was some suppression of the hypothalamic pituitary adrenal axis (Table VII).

\section{TABLE VII}

Third Study: Hypothalamic Pituitary Adrenal Function Tests in Patients who had Received Combined Prednisone and ACTH Therapy

\begin{tabular}{|c|c|c|c|c|}
\hline \multirow{3}{*}{$\begin{array}{l}\text { Case } \\
\text { No. }\end{array}$} & \multicolumn{4}{|c|}{ Plasma Cortisol $(\mu \mathrm{g} / 100 \mathrm{ml})$} \\
\hline & \multirow{2}{*}{$\begin{array}{l}\text { Resting } \\
9 \text { a.m. }\end{array}$} & \multirow{2}{*}{$\begin{array}{c}5 \text { hours } \\
\text { After } \\
40 \mathrm{U} \\
\text { ACTH }\end{array}$} & \multicolumn{2}{|c|}{ Maximal Response } \\
\hline & & & $\begin{array}{c}\text { Insulin } \\
\text { Tolerance Test }\end{array}$ & $\begin{array}{c}\text { Lysine } \\
\text { 8-Vasopressin }\end{array}$ \\
\hline $\begin{array}{l}13 \\
14 \\
15\end{array}$ & $\begin{array}{l}4 \cdot 2 \\
4 \cdot 0 \\
2 \cdot 0\end{array}$ & $\begin{array}{l}37 \cdot 8 \\
59 \cdot 8 \\
43 \cdot 2\end{array}$ & $\begin{array}{l}3 \cdot 6 \\
0 \cdot 6 \\
2 \cdot 4\end{array}$ & $\begin{array}{l}1 \cdot 2 \\
2 \cdot 8 \\
-\end{array}$ \\
\hline
\end{tabular}


Results were similar to the first study in that Case 14 showed an improved growth rate (Fig. 4), and this was associated with a rise in hydroxyproline output and a return of resting plasma cortisols to normal (Fig. 5). Case 13, whose growth did not improve during the first year but did so in the second, showed a slow return of the resting plasma cortisol to normal, but no increase in hydroxyproline excretion (Fig. 6). Antibodies to porcine ACTH were present in the serum of Case 14 who was growing, and not in Case 13 whose growth rate took more than one year to improve. Satisfactory resumption of growth followed withdrawal of prednisone in Case 15.

\section{Discussion}

Still's disease is a chronic disease leading to general ill health which itself may retard growth; in addition, interference with epiphysial development and fusion can further affect both local and overall growth. Osteoporosis secondary to immobility may cause collapse of vertebral bodies with further deterioration in height. Corticosteroids also suppress linear growth and can aggravate the osteoporosis (Blodgett et al., 1956; Van Metre, Niermann, and Rosen, 1960). The growth pattern

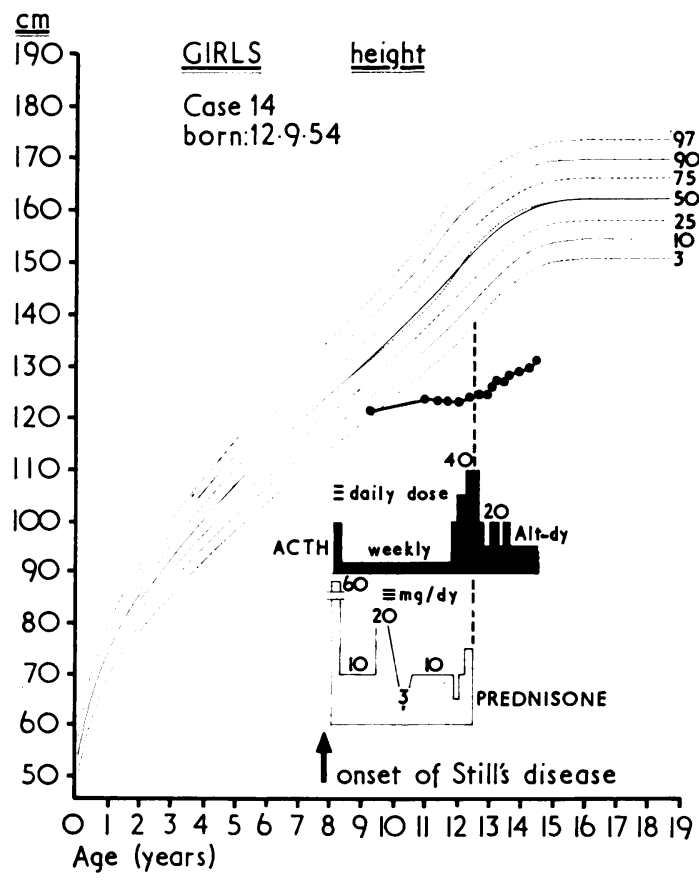

Fig. 4.-Case 14. Resumption of growth after stopping prednisone and establishment on ACTH only.

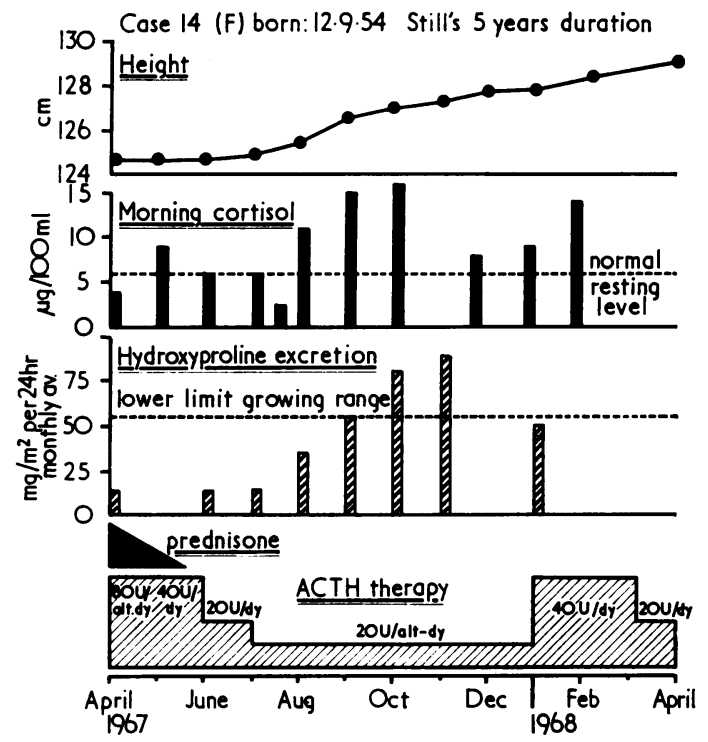

Fig. 5.-Case 14-E. Effect of replacing prednisone by ACTH on resting plasma cortisol levels and on hydroxyproline excretion; both show initially depressed levels, followed by rise to normal, coinciding with renewal of growth.

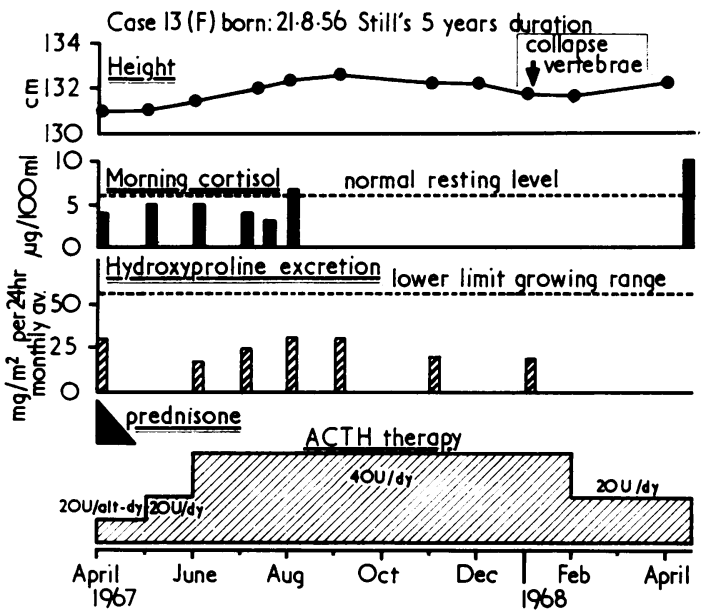

Fig. 6.-Case 13. Effect of replacing prednisone by ACTH. In contrast to Case 14 (Fig. 5) the resting plasma cortisols returned only slowly to normal. The lack of growth is reflected in the low hydroxyproline excretion.

observed in this study therefore reflects a combination of the disease process and the effect of therapy.

In those patients treated with ACTH who had not been on previous corticosteroid therapy, systemic manifestations were easily controlled as 
were the more acute arthritic manifestations. As dosage was reduced, it was not always easy to control the arthritis, so that gold therapy was continued in 2 and started in 2 children. Growth was maintained in all except 1 patient where the ACTH dosage was so high that she became grossly cushingoid. In 3 patients once the disease came under control ACTH was withdrawn without difficulty. Thus on the whole, our experience in Still's disease is in agreement with that in adult rheumatoid arthritis on the comparative ease of withdrawal of ACTH in contrast to corticosteroids (Savage et al., 1962; Nelson et al., 1966). In those patients converted from corticosteroid to ACTH, there was a temporary increase in disease activity. Despite this they tended to show an improved growth rate on ACTH therapy. Three of these patients showed signs of puberty while on ACTH so that this could, in part, account for their growth spurt. However, our experience of prolonged corticosteroid therapy when given for some years before puberty is that the normal pubertal growth spurt does not usually occur despite development of sexual maturation (Fig. 7). Kerribijn and de

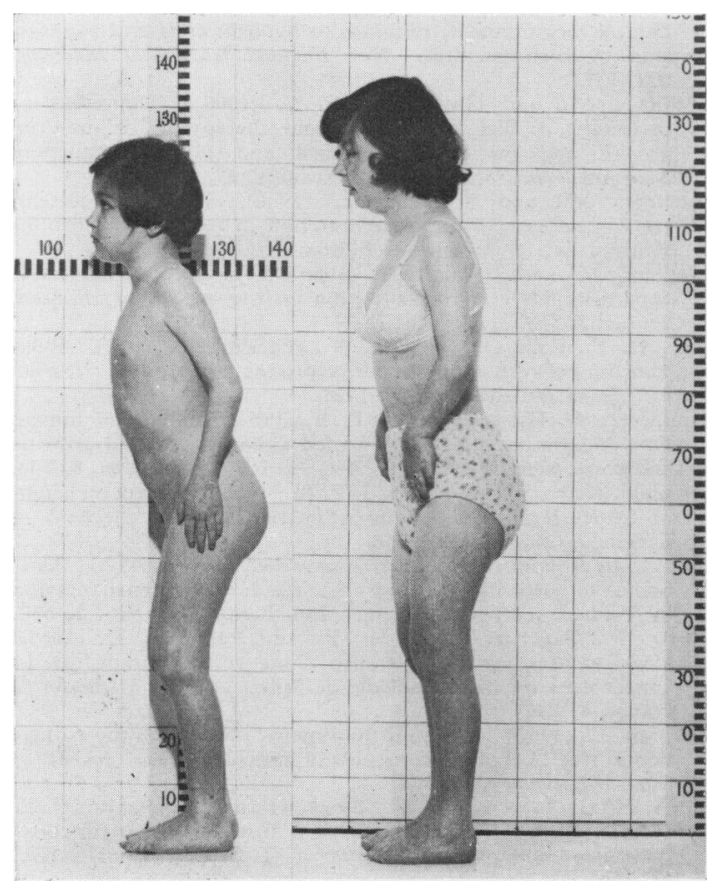

FIG. 7.-Girl with Still's disease beginning at age 6, maintained on approximately $5 \mathrm{mg}$ prednisone daily. (a) At age 8. (b) At age 18. Note growth of only $9 \mathrm{~cm}$ in 10 years despite evident occurrence of puberty.
Kroon (1968) also noted that skeletal maturation lagged behind sexual maturation in asthmatic patients treated with corticosteroid. Thus the main advantage of conversion to ACTH from corticosteroid therapy in these patients, whose disease was prolonged and severe, may have been in allowing the pubertal growth spurt to occur.

Measurements of the resting plasma cortisol level are a useful guide to prognosis for growth. In general when the 9.00 a.m. plasma cortisol taken 48 hours after an injection of ACTH had risen to normal, an increase in linear growth occurred. It has been our aim to stimulate the adrenal cortex for a limited period of time in order to maintain endogenous ACTH production. The most satisfactory preparation for treatment of patients with Still's disease is therefore one that stimulates the adrenal for a period of 12-15 hours, while allowing recovery of the hypothalamic pituitary adrenal axis in between each injection of ACTH. This can be achieved by the use of a preparation of ACTH suspended in gelatin. The longer acting preparations are unsuitable.

Serial estimations of urinary hydroxyproline excretion were not of value in predicting whether the change from corticosteroid to ACTH therapy would be effective in improving linear growth. Hydroxyproline excretion in the children who were receiving corticosteroids was depressed in accord with the findings of Smith, Ansell, and Bywaters (1968). Rise in excretion to the normal growing range after conversion to ACTH therapy was concurrent with rather than preceding resumption of growth.

The presence or absence of circulating antibodies to porcine ACTH bore no relation to the clinical response or the rate of growth in height. This is in agreement with the findings of Landon et al. (1967), and in contrast to the suggestion of earlier reports that acquired resistance to ACTH may have been due to antibody formation (West, 1960, 1962).

Due to the severity of the disease with involvement of the bones of the hands and carpus in our patients, no meaningful conclusions could be drawn as to the effect of ACTH therapy on skeletal maturation.

Osteoporosis severe enough to cause collapse of vertebrae does not appear to be a hazard of ACTH therapy, provided overdosage is avoided (see Case 6). Knowledge of plasma cortisol levels, whether basal or as a result of adrenal stimulation with ACTH, is therefore essential when this form of therapy is undertaken.

Suppression of the hypothalamic pituitary adrenal 
axis, as judged by basal plasma cortisol level and insulin tolerance test, after long-term low dosage corticosteroid therapy, does occur in Still's disease (Sturge et al., 1970) and the addition of ACTH to the corticosteroid regimen failed to preserve or restore a normal hypothalamic pituitary adrenal axis function in our patients. This agrees with the findings in adults (Carter and James, 1970a), Friedman and Greenwood (1968) have reported that long-term ACTH therapy in children does not suppress the hypothalamic pituitary adrenal axis to the same extent as corticosteroid treatment.

Suppression of growth by prolonged and continuous administration of corticosteroids can be followed by resumption of growth when the steroids are withdrawn. The cause of growth failure is not altogether clear; in part it may be due to inhibition of growth hormone secretion (Frantz and Rabkin, 1964; Friedman and Stimmler, 1966). The growth inhibitory effects of corticosteroids are, however, not reversed by the administration of growth hormone in above physiological amounts (Morris et al., 1968). Corticosteroids in doses that suppress growth suppress the production of endogenous ACTH and hence adrenal stimulation. It is of interest to speculate that the decreased adrenal stimulation may produce deficiency of an adrenal growth stimulating factor, which could be the cause of the growth retardation. In support of this hypothesis is the observation that corticosteroids administered intermittently on an alternate-day regimen may not suppress growth (Soyka, 1967). Corticosteroids given on alternate days allow for recovery of the hypothalamic pituitary adrenal axis and hence endogenous ACTH production in between each dose. ACTH suspended in gelatin given either daily or on alternate days is very similar to alternate-day corticosteroid therapy, in that it allows for recovery of the hypothalamic pituitary axis in between each injection (Friedman and Greenwood, 1968). This is of considerable advantage in that the ability to produce endogenous ACTH in response to stress is maintained (Carter and James, 1970b). However, long-acting ACTH preparations given frequently may have a similar. effect to continuous corticosteroid administration.

In patients converted from corticosteroid to ACTH therapy we have observed that an increase in linear growth only occurs when there is recovery of endogenous ACTH production. This may take many months or even up to a year. This slow recovery could explain why only 1 of the 6 stunted children with asthma studied by Norman and Sanders (1969) showed an increased growth rate after a 6-month period. Furthermore, the dosage of ACTH used may have been excessively high, and interfered with recovery of the hypothalamic pituitary adrenal axis.

We thank Drs. A. P. Norman, R. H. Dobbs, and O. Fisher for referring cases to us and allowing us to use their data, and Dr. J. Landon for examining sera for antibodies to ACTH. Dr. Margetts of Armours Pharmaceutical Co. Ltd. provided the ACTH.

\section{REPERENCES}

Ansell, B. M. (1968). Problems of corticosteroid therapy in the young. Proceedings of the Royal Society of Medicine, 61, 281.

Ansell, B. M., and Bywaters, E. G. L. (1956). Growth in Still's disease. Annals of the Rheumatic Diseases, 15, 295.

Ansell, B. M., and Bywaters, E. G. L. (1968). Still's disease. In Textbook of the Rheumatic Diseases, 4th ed. Chap. XII. Ed. by W. S. C. Copeman. Livingstone, Edinburgh.

Blodgett, F. M., Burgin, L., Iezzoni, D., Gribetz, D., and Talbot, N. B. (1956). Effects of prolonged cortisone therapy on the statural growth, skeletal maturation and metabolic status of children. New England fournal of Medicine, 254, 636.

Bywaters, E. G. L. (1965). The present status of steroid treatment in rheumatoid arthritis. Proceedings of the Royal Society of Medicine, 58, 649.

Carter, M. E., and James, V. H. T. (1970a). An attempt at combining corticotrophin with long-term corticosteroid therapy: with a view to preserving hypothalamic-pituitary-adrenal function. Annals of the Rheumatic Diseases, 29, 409.

Carter, M. E., and James, V. H. T. (1970b). Effect of corticotrophin therapy on pituitary-adrenal function. Annals of the Rheumatic Diseases, 29, 73.

Frantz, A. G., and Rabkin, M. T. (1964). Human growth hormone: clinical measurement, response to hypoglycemia and suppression by corticosteroids. New England fournal of Medicine, 271, $137 \bar{j}$.

Friedman, M., and Greenwood, F. C. (1968). The effect of prolonged ACTH or corticosteroid therapy in children on growth and on pituitary-adrenal and pitiutary function. Memoirs of the Society for Endocrinology, 17, 249.

Friedman, M., and Stimmler, L. (1966). Effect of corticotrophin on growth-hormone secretion in response to insulininduced hypoglycaemia in children. Lancet, 2, 944.

Friedman, M., and Strang, L. B. (1966). The effect of long-term corticosteroids and corticotrophin on the growth of children. Lancet, 2, 568.

Jasin, H. E., Fink, C. W., Wise, W., and Ziff, M. (1962). Relationship between urinary hydroxyproline and growth. fournal of Clinical Investigation, 41, 1928.

Kammerer, W. H., and Stokes, P. E. (1962). Effects of human growth hormone in a girl dwarfed from rheumatoid arthritis and corticosteroid therapy. Arthritis and Rheumatism, 5, 304.

Kerrebijn, K. F., and de Kroon, J. P. M. (1968). Effect on height of corticosteroid therapy in asthmatic children. Archives of Disease in Childhood, 43, 556.

Landon, J., Friedman, M., and Greenwood, F. C. (1967). Antibodies to corticotrophin and their relation to adrenal function in children receiving corticotrophin therapy. Lancet, 1, 652.

Louyot, P., Gaucher, A., Benoit, P., and Rabouille, D. (1965). Conséquences sur la croissance d'une corticothérapie de 14 années dans un cas de maladie de Still. Annales Médicales de Nancy, 4, 48.

Mattingly, D. (1962). A simple fluorimetric method for the estimation of free 11-hydroxycorticoids in human plasma. Fournal of Clinical Pathology, 15, 374.

Morris, H. G., Jorgensen, J. R., Elrick, H., and Goldsmith, R. E. (1968). Metabolic effects of human growth hormone in corticosteroid-treated children. fournal of Clinical Investigation, 47, 436.

Nelson, J. K., Mackay, J. S., Sheridan, B., and Weaver, J. A. (1966). Intermittent therapy with corticotrophin. Lancet, 2, 78.

Norman, A. P., and Sanders, S. (1969). Effect of corticotrophin on skeletal maturation and linear growth in six patients with severe asthma. Lancet, 1, 287. 
Savage, O., Copeman, W. S. C., Chapman, L., Wells, M. V., and Treadwell, B. L. J. (1962). Pituitary and adrenal hormones in rheumatoid arthritis. Lancet, 1, 232.

Smith, M., Ansell, B. M., and Bywaters, E. G. L. (1968). Urinary hydroxyproline excretion in patients with juvenile rheumatoid arthritis, with and without corticosteroid therapy. Fournal of Pediatrics, 73, 875.

Soyka, L. F. (1967). Treatment of the nephrotic syndrome: use of an alternate-day prednisone regimen. American fournal of Diseases of Children, 113, 693.

Stimmler, L., and Brown, G. A. (1967). Growth hormone secretion provoked by insulin-induced hypoglycaemia in children of short stature. Archives of Disease in Childhood, 42, 232.

Sturge, R. A., Beardwell, C., Hartog, M., Wright, D., and Ansell, B. M. (1970). Cortisol and growth hormone secretion in relation to linear growth: patients with Still's disease on different therapeutic regimens. British Medical fournal, 3, 547.

Tanner, J. M., and Whitehouse, R. H. (1967). Growth response of 26 children with short stature given human growth hormone. British Medical fournal, 2, 69.
Tanner, J. M., Whitehouse, R. H., and Takaishi, M. (1966). Standards from birth to maturity for height, weight, height velocity, and weight velocity: British children, 1965. Archives of Disease in Childhood, 41, 613.

Van Metre, T. E., Jr., Niermann, W. A., and Rosen, L. J. (1960). A comparison of the growth suppressive effect of cortisone, prednisone, and other adrenal cortical hormones. fournal of Allergy, 31, 531.

Ward, D. J., Hartog, M., and Ansell, B. M. (1966). Corticosteroidinduced dwarfism in Still's disease treated with human growth hormone. Annals of the Rheumatic Diseases, 25, 416.

West, H. F. (1960). Adrenocorticotropins and their use. Acta Medica Scandinavica, Suppl., 352.

West, H. F. (1962). Ten years of ACTH therapy. Annals of the Rheumatic Diseases, 21, 263.

Correspondence to Dr. Barbara M. Ansell, M.R.C., Rheumatism Unit, Canadian Red Cross Memorial Hospital, Taplow, Maidenhead, Berkshire. 